\title{
A MANIPULÁCIÓ MÜVÉSZETE. A MACHIAVELLIZMUS KOGNITÍV ÉS EVOLÚCIÓS ALAPJAI*
}

\author{
BERECZKEI TAMÁS
}

PTE BTK Pszichológia Intézet

E-mail: bereczkei.tamas@pte.hu

Beérkezett: 2014. október 10. - Elfogadva: 2014. december 20.

Az elmúlt évtizedben meglepö fordulatok következtek be a machiavellizmus kutatásában. Miközben az 1960-as, 1970-es évek klasszikus szociálpszichológiai kísérleteinek számos következtetése tarthatónak bizonyult, néhány esetben számottevő újraértelmezésekre került sor. A machiavellisták valóban racionálisan gondolkodó, „,hidegfejü” emberek, de úgy tünik, intenzív érzelmeket élnek át a társas kapcsolataikban, amelyeket viszont jól lepleznek, és ez segitheti a megtévesztés sikerességét. Minden elözetes elvárás ellenére rossz elmeolvasónak bizonyultak, de képesek lehetnek arra, hogy pontos megállapításokat tegyenek potenciális áldozataik tipikus jellemvonásairól, különösen olyan helyzetekben, amelyek lehetövé teszik a manipulációt. Vágynak az azonnali nyereségre, de képesek hosszú távon is gondolkodni, amennyiben rugalmasan igazíták döntéseiket a szituáció pillanatnyi állásához. Mindez összhangban lehet az ún. Machiavelli-intelligencia evolúciós hipotézisével, amely szerint a csalás és a manipuláció központi szerepet játszott a föemlösök - benne az ember agyának növekedésében és kognitív képességeinek fejlödésében. A társak szisztematikus és eredményes manipulációja valóban erőteljes szelekciós erö lehetett a múltban, de ez valószínüleg nem az elmeolvasás és intelligencia kidolgozásához vezetett (azt más evolúciós folyamatok végezhették), hanem a környezet specifikus jellemzőinek a pontos kiértékeléséhez, a csoporttársak árnyalt kategorizálásához és a rugalmas döntéshozatalhoz.

Kulcsszavak: érzelmi intelligencia, elmeolvasás, kognitív heurisztikák, szociális intelligencia

\footnotetext{
*A kutatást az Országos Tudományos Kutatási Alapprogramok - OTKA (K-101762) támogatta.
} 


\section{ÉRZELMI HIDEGSÉG}

A kutatások kezdete óta a machiavellisták alapvető jellemzői közé sorolják racionális, hűvös, távolságtartó viselkedésüket. Florence Geis és munkatársai laboratóriumi megfigyeléseik során állapították meg, hogy a magas Mach-pontszámokkal rendelkező személyek személytelen attitűdöt mutatnak partnereik iránt, függetlenítik magukat a személyes kapcsolatok érzelmi légkörétől, és általában nem törődnek mások érzéseivel és céljaival (GEIS és LEVY, 1970; GEIS, WEINHEIMER és BERGER, 1970). A szerzők arra vonatkozóan is figyelemre méltó feltevéseket fogalmaznak meg, hogy ez az érzelmi visszafogottság miként befolyásolja a manipulációra vonatkozó döntéseket. Az érzelmi torzítás zajonci modelljét (ZAJONC, 1965) felhasználva azt vetik fel, hogy miután a magas Mach-személyek nem törődnek a személyes elköteleződésekkel és érzésekkel, a kapcsolat érzelmi tartalma nem zavarja a tisztánlátásukat. Ellenkezőleg, teljes figyelmet szentelnek a szituáció kognitív elemzésének, és csak a stratégiai célok elérésére koncentrálnak. Az alacsony Machok ezzel szemben nem tudják magukat függetleníteni a személyes bevonódásoktól és az érzelmi felhangoktól, és ez könnyen megosztja figyelmüket és eltereli gondolkodásukat. Ez magyarázhatja azokat a kísérleti eredményeket, amelyek szerint a machiavellisták elsősorban az érzelmi töltéssel rendelkező helyzetekben teljesítenek másoknál jobban - amikor például érvelni kell valamilyen társadalmi intézmény szerepével kapcsolatban, vagy leplezniük kell a hazugságaikat (GEIS, WeINHEIMER és BERgER, 1970; SUlLiVAN és ALLEN, 1999).

A későbbi kutatások nagymértékben támaszkodtak ezekre a megfontolásokra. Többen úgy érvelnek, hogy az érzelmi hidegség az erős impulzuskontrollra vezethető vissza, amely ebben az összefüggésben elsősorban a szituáció szenvedélymentes elemzését és a mások iránti közömbösséget jelenti (JONES és PAULHUS, 2009; PILCH, 2008). Jones és PAulhus (2009) szerint az impulzuskontroll tekinthető a machiavellisták alapvető tulajdonságának, és ebből fakadnak a sikeres manipulációval kapcsolatos egyéb jellemzőik. Nevezetesen, hogy képesek koncentrálni a célra, elemezni az adatokat, szelektálni a lehetséges taktikai lépések között, és kiválasztani az optimális stratégiát mindegyik szituációban. Az érzelmi hidegség (impulzuskontroll) ebből a szempontból adaptív tulajdonságnak tekinthető, hiszen a mások iránt mutatott érzéketlenség megakadályozza az áldozatra hangolódást, ami pedig elősegítheti eredményes kihasználásukat. Ráadásul a mások iránti érzelmi rezonancia hiánya csökkentheti az olyan belső szabályozók működését, mint a szégyen vagy a büntudat, ami szintén a sikeres kizsákmányolást valószínűsíti (MCILlWAin, 2003).

Az említett kutatási eredmények és elméleti megfontolások azonban keveset mondanak a „hidegfejü” gondolkodás kognitív mechanizmusairól. Lehetséges, hogy a machiavellisták egyáltalában nem élnek át érzelmeket, vagy csak nem tudják, esetleg nem akarják kimutatni ezeket? A jelenlegi vizsgálatok eltérő válaszokat adnak ezekre a kérdésekre. Egyesekben azt találták, hogy a machiavellisták (és az elsődleges pszichopaták) másokhoz képest több pozitív érzelemről számoltak be, amikor szomorú arcokat ábrázoló képeket mutattak nekik (SAM teszt) (ALI, Amorim és Chamorro-Premuzic, 2009; Wai és Tiliopoulus, 2012). Lehetséges, 
hogy nehézségeik vannak a negatív érzelmek átélésében, ezért mások szenvedése nem feltétlenül okoz bennük lehangoltságot vagy feszültséget. Ugyanezek a kísérletek azt mutatják, hogy a machiavellisták negatív érzelmeket táplálnak a boldog (vagy neutrális) arckifejezések láttán. Ez utóbbinak a magyarázata nem világos, bár egyes szerzők (WAI és TILIOPOULUS, 2012) emlékeztetnek arra, hogy a pszichopaták esetében rendellenességet találtak az amygdalában, amelyről köztudott, hogy az érzelmi válaszok koordinálásában vesz részt.

Más vizsgálatok ugyanakkor arra mutatnak rá, hogy a machiavellisták az átlagosnál erőteljesebb negatív érzelmeket élnek át, különösen stresszhelyzetekben. Egy személyiségdiagnosztikai kérdőív felhasználásával készült beszámoló szerint a magas Mach-egyének hajlamosak az érzelmi nyugtalanságra és a robbanékonyságra (MCHoskeY, 2001). Egy hazai vizsgálatból, amely többek között a BFI ötfaktoros személyiségtesztet használta, az derült ki, hogy a magas Mach-pontokkal rendelkező emberek érzelmi stabilitása különbözik alacsony pontszámú társaikhoz képest: több negatív érzelmet élnek át, hamarabb elvesztik higgadtságukat, és könnyen kijönnek a sodrukból (SZIJJÁRTó és BERECZKEI, 2014). Általában véve jobban megviselik őket az érzelmileg megterhelő események, és nehezebben viselik a feszültséget (distressz). Ezek az eredmények arra engednek következtetni, hogy a sokszor hűvös, racionális gondolkodásúnak, sőt „hidegfejünek” leírt machiavellistákban komoly belső indulatok és feszültségek húzódnak.

Persze nem véletlen, hogy a külső megfigyelők mégis inkább higgadt, fegyelmezett, értelemvezérelt embereknek látják őket. A vizsgálatokból ugyanis az is egyértelműen kiderül, hogy a machiavellisták meglehetősen rosszul fejezik ki az érzelmeiket. Egyfajta visszafogottság jellemző rájuk, úgy tűnik, szigorú ellenőrzés alatt tartják a különböző megnyilvánulásaikat (MCHoskey, 1999). A már említett hazai vizsgálatban, ahol az érzelmi intelligencia különböző faktorait mérték egy erre alkalmas kérdőíven (Schutte-féle Önbeszámolós Érzelmi Intelligencia Skála), azt találták, hogy a magas Mach-pontszámokkal rendelkező személyek a többiekhez képest rosszabbul fejezik ki érzelmeiket (SzIJJÁRTó és BERECZKEI, 2014). A machiavellisták saját bevallásuk szerint a verbális kommunikáció során nem tudják árnyaltan és pontosan érvényre juttatni a bennük keletkező érzéseket és indulatokat. Hasonló eredményekkel jártak azok a vizsgálatok, amelyekben a kísérleti személyeknek idegen emberek érzelemkifejezéseit kellett felismerniük és azonosítaniuk (Austin, FArrelly, BlaCk és MoOre, 2007; Wai és Tiliopoulis, 2012). Általánosságban azt lehet mondani, hogy a machiavellistáknak nehézségeik vannak mind saját érzelmeik kommunikációjával, mind pedig mások érzelmeinek a megértésével.

Lehetséges, hogy a fenti hiányosságok éppenséggel előnyösek lehetnek mások megtévesztése során. Az érzelmek visszafogott kommunikációja elősegítheti a manipuláció sikerességét, hiszen a potenciális áldozat számára nem jelennek meg azok a viselkedési kulcsok, amelyek alapján tájékozódni tudna a machiavellista szándékairól. Nem tudja, hogy mi rejtőzik a machiavellista „pókerarca” mögött, és sokszor nem sejti, hogy a közömbös attitűd egy lehetséges támadás előfutára.

Arról viszont egyelöre nagyon keveset tudunk, hogy van-e szándékosság az érzelemkifejezések hiányos működése mögött. Lehetséges, hogy a machiavellisták 
szándékosan leplezik érzelmeiket, hogy a megtévesztés tökéletes legyen. Érzelmeik kifejezésének gátlása során képessé válhatnak arra, hogy bármilyen érzések is jönnek létre bennük egy érzelmileg megterhelő szituációban, higgadtnak mutathassák magukat. Ebben az esetben el lehet képzelni, hogy az evolúció során alakultak ki azok a gátló folyamatok, amelyek - egyfajta proximatív mechanizmusként - a machiavellista törekvések szolgálatában állnak. Az is lehetséges azonban, hogy egy tényleges kognitív deficitről van szó, amely történetesen összekapcsolódik a manipulatív motivációkkal. Az érzelmek kifejezésére való képtelenség, működéshiány ezen az úton is hozzásegítheti a machiavellistát ahhoz, hogy valódi szándékai ne kerüljenek felszínre, és ezzel a pszichés deficit ugyancsak a befolyásolás eszközévé válhat. Itt sem nehéz segítségül hívni a lehetséges evolúciós magyarázatokat: a megfelelő érzelemkifejezésekre való képtelenség ugyan számos hátránnyal jár a személyközi kapcsolatokban, de a manipulatív viselkedés előnyei mintegy ellensúlyozták ezeket a hátrányokat, és együttesen egy adaptív viselkedési komplexumként fejlődtek ki az evolúció során (BERECZKEI, 2003).

Ami az ide vonatkozó tapasztalati adatokat illeti, a kép meglehetősen zavaros. A kísérleti eredmények mindkét feltevést alátámasztani látszanak. A leplezés szándékossága mellett szólnak azok a tények, amelyek azt mutatják, hogy a machiavellista jól leplezi a hazugságait, és meggyőzően tagadja a csalás tényét (Exlinne, Thiabaut, Hickey és Gumpart, 1970; Harrell és Hartnagel, 1976). Egy jelenlegi vizsgálat viszont inkább a másik - a deficitre vonatkozó - hipotézist támasztja alá. Ennek az eredményei azt sugallják, hogy a machiavellisták nem csupán a saját érzelmek kifejezése terén mutatnak elmaradást másokhoz képest, hanem érzelmeik azonosítása és megkülönböztetése tekintetében is (SZIJJÁRTÓ és BERECZKEI, 2013). Nehézségeik adódnak saját érzelmeik „címkézésével", nehezebben értik meg ezeknek az érzelmeknek a valódi jelentését, és gyengébb teljesítményt mutatnak a bennük keletkező érzelmek közti átmenetek észlelésében. Nyilvánvalóan több kutatást kell végezni ezen a téren a jövőben, hogy tisztább képet kapjunk a machiavellisták érzelemszabályozásáról.

\section{ELMEOLVASÁS}

A machiavellizmussal kapcsolatos kutatásokkal egyidős az a feltevés, hogy a machiavellisták jó emberismerők, és hogy az emberekre vonatkozó tapasztalataikat, benyomásaikat készségesen állítják a manipuláció és megtévesztés szolgálatába (GEIS és LEVY, 1970). A későbbiekben, amikor az elmeolvasás (elmeteória, mentális állapottulajdonítás) fogalma meghatározóvá vált a kognitív pszichológiában, a kutatók körében egyértelműnek adódott az a feltételezés, hogy a machiavellisták kiváló elmeolvasók, azaz képesek következtetéseket tenni mások elmetartalmaira. Ügyesek annak megállapításában, vagy legalábbis feltételezésében, hogy mások mit gondolnak, mit éreznek, mire törekszenek, mit tudnak vagy nem tudnak. A machiavellisták jó elmeolvasókként való beállítása nyilvánvalóan következett abból a megalapozottnak látszó feltevésből, hogy a manipuláció és a megtévesztés csak úgy múködik, ha valaki képes a másik fejével gondolkodni. Fejlett elmeteória 
nélkül aligha volna lehetséges, hogy valaki sikeresen manipuláljon másokat, és felismerje mások - néha talán még saját maguk számára sem tudatos - gyenge pontjait (PAÁl és BERECZKEI, 2007).

Kiderült azonban, hogy a machiavellisták nem rendelkeznek átlag feletti képességgel annak megértése és értelmezése terén, hogy a másik mit gondol vagy érez. Az első ilyen kísérletben a kutatók különböző történeteket meséltek a kísérleti személyeknek, és megkérték őket, hogy válaszoljanak azokra a kérdésekre, amelyek a történetben szereplő személyek feltételezhető vélekedéseire, céljaira, gondolataira vonatkoztak (PAÁL és BERECZKEI, 2007). Az elméleti elvárások fényében meglepetésként hatott, hogy a magas Mach-pontszámokkal rendelkező személyek egyáltalában nem teljesítettek jobban, mint alacsony pontszámú társaik. Sőt, a későbbi kutatások egyértelmű negatív összefüggést tártak fel a machivellizmus és az elmeolvasó képesség szintje között. Bármilyen módszert használtak, az derült ki, hogy a machiavellisták az átlaghoz képest rosszul értelmezik mások mentális tartalmait. Viszonylag gyengén teljesítenek a történetek értelmezésében, és ugyancsak alacsony pontszámot érnek el az ún. „szempár teszten", ahol az arc felső részének - a tekintetnek - a megfigyeléséből kellett következteni arra, hogy a szempár tulajdonosa milyen belső állapotokkal, érzésekkel vagy érzelmekkel rendelkezhet (LYONS, CALDWELL és SCHULTZ, 2010; Ali és Chamorro-Premuzic, 2010). Szintén negatív összefüggést találtak a machiavellizmus és az elmeolvasás között abban a tesztben, ahol semleges, negatív, illetve pozitív érzelmeket mutató arcokat kellett értelmezni (ALI és CHAMORROPREMUZIC, 2010). Sőt, a magas Mach-személyek az alacsonyokhoz képest rosszabbul teljesítettek abban a tesztben (RMVT), ahol a beszélő érzelmeit kellett azonosítani egy rövid szöveg felolvasása után (Ali és Chamorro-Premuzic, 2010). Nehézségeik voltak még annak a megítélésében is, hogy a beszélő semleges, negatív vagy pozitív érzelmeket kommunikál. Nem meglepő ezek után, hogy a machiavellisták gyenge teljesítményt mutattak azokon a teszteken is, ahol az érzelmi intelligenciát és az empátiát mérték (PAál és BERECZkei, 2007; Ali és ChamorroPremuZic, 2010, Austin és mtsai, 2007). Nem igazolódott tehát be, hogy azok, akik inkább hajlanak mások manipulálására, félrevezetésére és eszközként való felhasználására, jobb elmeállapot-tulajdonító képességgel rendelkeznek másokhoz képest.

A nagy kérdés ezek után, hogy ha valaki az átlagosnál gyengébb mások ismereteinek, céljainak, illetve érzelmi állapotainak a felismerésében, és kevésbé érzékeny a finom társas jelzésekre, hogyan lehet mégis képes sikeresen manipulálni más embereket? A kérdés nem egyszerű, és jelenleg nincs is egyértelmű válaszunk rá. Az egyik lehetőség, hogy az eddigi mérések pontosan és valósághűen tárták fel az egyéni különbségeket, és a machiavellisták tényleg hiányosságokat mutatnak a szociális megismerés területén. Ebben az esetben - a szükségből erényt csinálva úgy érvelhetünk, hogy ez a deficit éppenséggel a manipuláció és a megtévesztés szolgálatában állhat, hiszen mások megértésének a hiánya segítheti a machiavellisták ügyeskedéseit. Ha nem fogják fel mások negatív érzelmeit, vagy nem értik meg mások szenvedésének okát, sikeres manipuációjukat kevésbé fogják zavarni rossz érzések vagy lelkiismeret-furdalások. 
Ez az elképzelés összhangban van azokkal a korábban említett vizsgálati eredményekkel, miszerint a machivellisták képesek érzelmeket átélni, de ezeket elrejtik. Lehetséges, hogy van valamiféle empatikus rezonálásuk mások problémájára és szenvedésére, de ezt elnyomják, és ez a gátlás szabaddá teszi az utat az eredményes kizsákmányolás előtt. Ugyanakkor egy súlyos probléma is felmerül ezzel az elképzeléssel szemben. Nevezetesen, hogy a gyenge elmeolvasó képességből fakadó társas ügyetlenség veszteségei alighanem felülmúlják az érzéketlenség lehetséges előnyeit. Azaz, hiába a bűntudat hiánya, ha valaki nem képes megérteni a másik felet, valószínűleg nem fogja tudni félrevezetni.

Egy másik lehetséges magyarázat a machiavellismus és az elmeolvasás negatív összefüggésére úgy szól, hogy az eddig használt elmeolvasó tesztek messze nem tökéletesek: nem tudják mérni a finom, rejtett szociális jelzésekre adott egyéni válaszok különbségeit. Elképzelhető például, hogy a machiavellisták bizonyos társas szituációkat és bizonyos emberi attitűdöket nagyon is jól kódolnak - elsősoban azokat, amelyek szükségesek a manipulációhoz. Egy jelenlegi vizsgálatban a kísérleti személyeknek történeteket kellett megérteni a benne szereplő személyek perspektívájának átvétele révén (lásd Szabó Edit és Bereczkei Tamás tanulmányát ebben a kötetben, a 37-53. oldalon). A magas Mach-pontszámokkal rendelkező személyeknek továbbra is nehézségeik voltak a „hagyományos” történetek megértése terén alacsony pontszámú társaikhoz képest. Lényegesen jobban teljesítettek ellenben akkor, ha a történetek egy-egy nyilvánvalóan és szándékosan megtévesztő esetet írtak le. A machiavellisták itt „otthonosan mozogtak”; másokhoz képest nagyobb pontossággal ismerték fel, hogy másokat (a történet szereplőit) manipulálják. Lehetséges, hogy a megértésben és a végrehajtásban hasonló kognitív mechanizmusok vesznek részt: aki maga is hajlamos különböző megtévesztő taktikák alkalmazására, az érzékenyebb ezek felismerésében is. Az eredményből talán azt az általános következtetést is leszűrhetjük, hogy a machiavellista személy akkor és ott használja fel kognitív erőforrásait, ahol ennek értelme és haszna van (ti. a manipulatív helyzetekben).

A következő magyarázat szorosan kapcsolódik az előző szakaszban bemutatott eredményhez, de azt egy másik elméleti perspektívába helyezi. Arról van szó, hogy egyes szerzők különbséget tesznek az elmeteória ún. idiografikus és nomotetikus formája között (MCILLWAIN, 2003). Az idiografikus elmeolvasás az egyéni különbségekre koncentrál, és azt méri föl, hogy valaki milyen mértékben képes arra, hogy következtetéseket és előrejelzéseket tegyen egy másik személy aktuális mentális állapotára vonatkozóan. Ezt szokták klasszikus értelemben elmeteóriának nevezni, és erre irányul a kutatások nagy része. A nomotetikus elmeolvasás jóval elhanyagoltabb kutatási terület, annak ellenére, hogy lényeges és gyakran alkalmazott mentális műveletről van szó. Ennek keretében az egyén nem a másik ember itt és most létező elmetartalmait fürkészi, hanem múltbeli tapasztalatai alapján próbál általánosítani a másik személy „típusára”. Nem az a fontos számára, hogy a másik pillanatnyilag mit tud, mire gondol, és mire vágyik, hanem az, hogy hasonló emberek hasonló helyzetekben hogyan szoktak gondolkodni és cselekedni. Lehetséges, hogy a machiavellista nomotetikus gondolkodással próbálja megérteni a másik ember lehetséges viselkedési indítékait és várható cselekedeteit. 
A gyerekkorában és később átélt tapasztalatait, benyomásait egy új szituációra alkalmazva típusokat alkot, és ez alapján hoz döntést a manipuláció lehetséges formáiról és várható sikerességéről.

Nagyon is úgy tűnik ezzel kapcsolatban, hogy sokszor az emberek gyengesége és sebezhetősége ad lehetőséget a sikeres manipulációra. Nem szükséges a másik személy mentális állapotait pontról pontra és pillanatról pillanatra követni, ha egyébként az ember természeténél fogva annyira sebezhető, hogy könnyen áldozattá válik. Az emberi gyengeség olyannyira meghatározó az áldozattá válásban mondja Doris MCILlWAIN (2003) -, hogy azt alig tudjuk elképzelni. Számos hamis hitet táplálunk magunk iránt, amely megfoszthat bennünket a védekezéstől. Jobbnak hisszük magunkat, mint amilyenek a valóságban vagyunk, kedvezőbb ítéleteket alkotunk attitűdjeinkről és törekvéseinkről, mint ami a viselkedésünkben ténylegesen megjelenik, és sokszor más indokot tulajdonítunk cselekvéseinknek, mint amilyen céllal azok valójában létrejöttek. Ehhez járul még számos olyan emberi tulajdonság, amelyek megkönnyíthetik mások számára, hogy félrevezessenek bennünket: félelem, bű̉ntudat, hiúság, bizonytalanság, vágyfantázia és így tovább. Bizonyos helyzetekben ezek az önbecsapások és jellemhibák olyan sebezhetőséget jelentenek, amelyek nyitva hagyják a lehetőséget, hogy a manipuláció áldozatává váljunk (MCILlwain, 2003). A machiavellista ügyesen használja ki ezt a lehetőséget, amennyiben tapasztalatból tudja, hogyan „müködik” az ember, szemben azzal, ahogyan az emberek saját magukról vélekednek.

A machiavellisták sokszor úgy érik el céljukat - még ha nem képesek is tökéletesen megérteni, hogy mi van a másik fejében -, hogy olyan mentális állapotokat hoznak létre másokban, amelyek már sikeresen manipulálhatók. Ilyen a bűntudat felkeltése, amelyet a machiavellisták sikeresen használnak másokkal szemben (VANGELISITY, DALY és RUDNICK, 1991). Olyan taktikákat foglal magában, mint „emlékeztetni másokat arra, hogy milyen kötelezettségeik vannak egy ilyen kapcsolatban”, „hivatkozni a másik felelősségére valamilyen szituációban”, „felsorolni azokat a cselekedeteket, amelyeket a másikért hoztunk a múltban”, és így tovább. Miközben természetesen sokan élnek a bűntudatkeltés eszközével - akár tudatosan, akár nem tudatosan -, a machiavellistákra jellemző egyfajta gyakorlatiasság és könnyedség ennek a lélektani folyamatnak a kiaknázásában. Ilyeneket mondanak például magukról: „Amikor mérges vagyok valakire, gyakran intézem úgy a dolgot, hogy a másik bűntudatot érezzen”, vagy: „Nem esik nehezemre másokban bűntudatot kelteni”.

Az elmondottak szerint tehát a machiavellista képes megérteni és beépíteni a gondolkodásába azokat az általános emberi tulajdonságokat, amelyek potenciálisan sebezhetővé teszik az áldozatukat. Nem szükséges feltételeznünk, hogy pontos következtetéseket tesz a vele szemben álló személy egyedi és aktuális mentális állapotaira, de azt igen, hogy képes felismerni az áldozatok típusait, és képes olyan mentális állapotokat indukálni az áldozatban, amelyet már a saját céljaira tud felhasználni egy meghatározott szituációban. 


\section{RUGALMAS GONDOLKODÁS}

Az utóbbi évek kutatásainak egyik fontos felismerése, hogy a machiavellisták sikere jelentős részben rugalmas gondolkodásuknak és gyors alkalmazkodóképességüknek köszönhető. Természetesen ez nem teljesen új felismerés: már az 1970-es évek „klasszikus” szociálpszichológiai munkáiból az derül ki, hogy a machiavellisták ügyesen kontrollálják a viselkedésüket befolyásoló feltételeket, és opportunista módon használják ki a lehetőségeiket. Egy kísérletben, ahol a résztvevők kártyajátékot játszottak, a machiavellisták másoknál gyakrabban nyertek, mert ügyesebbek voltak abban, hogy korábbi ellenfeleiket rábírják a velük való együttműködésre, így nagyobb összeg elnyerésére (GEIS, 1970). Amikor a játékosoknak ígéretet kellett tenniük, hogy később sem rombolják le ezt a szövetséget, a magas Machszemélyek inkább betartották az ígéretüket, mint az alacsony Machok. Abban az esetben viszont, amikor ők voltak azok, akik ígéretet kértek partnerüktől - és azt a partner betartotta -, a machiavellisták nagy valószínűséggel megszegték saját ígéretüket, és ezzel nagyobb nyereményre tettek szert.

Újabb vizsgálatok megerősítik a machiavellisták taktikai rugalmasságával kapcsolatos korábbi eredményeket. Az egyik kísérletben a résztvevőktől azt kérdezték, milyen gyakran használnak bizonyos taktikákat mások befolyásolására (JONASON és WEBSTER, 2012). A csábítástól kezdve a könyörgésen és a másik felelősségére történő hivatkozáson keresztül a pénzjutalom felajánlásáig, nagyon széles skálán mozogtak ezek a befolyásolási technikák. Sokkal szélesebb skálán, mint a machiavellizmushoz kapcsolódó másik két csoportban: a pszichopátia és a nárcizmus magas pontszámait viselők körében (amely a machiavellizmussal együtt az ún. Sötét Triászt alkotja, lásd Paulhus és Williams, 2002). Ráadásul kiderült, hogy ezeknek a taktikáknak az alkalmazása a célcsoportok függvényében is változik: így például a machiavellisták elsősorban a kellemes, megnyerő modort vetik be, amikor azonos nemű barátaikkal szeretnének valamilyen közös dologba fogni. Más területen - így családtagjaik vagy ellenkező nemü ismerőseik körében - viszont más befolyásolási módszert alkalmaznak.

A szerzők mindezt egyfajta „próteuszi” karakterként értelmezik, amennyiben a machiavellisták állandóan változtatják és az adott körülményekhez igazítják döntéseiket mások befolyásolása és manipulálása érdekében. Valójában tehát a felhasználható technikák egész tárháza áll rendelkezésükre, amely egy mindenkor változtatható eszközkészletet alkot a számukra. Nem csupán arról van azonban szó, hogy ezek közül kiválasztják az adott körülmények között éppen megfelelő eszközt, hanem arról is, hogy ezzel megnehezítik a leleplezésüket. A sokféle és sokirányú befolyásolási lehetőségek ugyanis csökkentik viselkedésük bejóslásának a lehetőségét. Azzal járnak, hogy potenciális áldozataik nehezen ismerik fel és jelzik előre, milyen lépések várhatók a jövőben ellenlábasaik részéről. A manipulációs ügyességben mutatkozó próteuszi attitűdnek ezért fontos adaptív jelentősége van: képviselőik csökkentik a leleplezés kockázatát, és állandóan kitérnek a másik fél ellencsapásainak az útjából.

Hazai vizsgálatok tovább árnyalják ezt a képet. A kutatások egy része számítógépes kísérleti játékokat használt (elsősorban Közjavak játékot), amely alkalmas 
volt életszerủ egyéni interakciók tanulmányozására. Az egyikből az derült ki, hogy a magas Mach-pontokkal rendelkező személyek a játék végére több pénzt nyernek (és vihetnek haza), mint az alacsony Mach-személyek, pontosan azért, mert döntéseiket rugalmasan igazítják partnereik viselkedéséhez (CZIBOR és BERECZKEI, 2012). A regressziós elemzésből kitűnt, hogy folyamatosan monitorozzák ellenfeleiket, és azok korábbi lépései alapján hoznak döntést saját befizetéseikről. Egy másik vizsgálatból az derült ki, hogy míg az alacsony Machok viselkedését elsősorban személyiségtényezők (például kitartás) befolyásolják, a magas Machok inkább a szituáció sajátosságai alapján alakítják ki lépéseiket (BERECZKEI és CzIBOR, 2014). Másokhoz képest nagyobb figyelmet szentelnek annak, hogy játékostársaik között vannak-e „altruisták” (akik a rendelkezésükre álló pénzösszeg több mint 80\%-át adják a közösbe) és „csalók” (akik kevesebb, mint 20\%-ot fizetnek be). Amikor egy újabb kísérletben a játékosoknak lehetősége nyílt arra, hogy egymást követően részt vegyenek egy kifejezetten versengő játékban és egy olyanban, ahol az együttműködésre irányult nagyobb elvárás, a machiavellisták az utóbbi helyzetben folyamodtak leginkább a potyaleső stratégiához (BERECZKEI és CZIBOR, megjelenés alatt). Amikor ugyanis mindenki versenyzett, nem sok tere nyílt a csalásnak, amikor viszont az együttműködés vált követendő stratégiává, a machiavellista egyének sikeresen fölözték le mások közadakozásait.

Agyi képalkotó eljárások is megerősítik azt a képet, hogy a machiavellisták rugalmas döntéshozók, akik figyelik a partnerek és a szituáció változásait, és azokhoz igazítják lépéseiket. Egy svájci vizsgálatban a PET-készülékben fekvő személyek egy kétszemélyes játékot játszottak, amelynek második részében lehetőség volt a potyalesők büntetésére (SPITZER, FISCHBACHER, Herrnberger, Grön és FEHR, 2007). A viselkedéses adatok azt mutatták, hogy a magas Mach-személyek több pénzt vihettek haza a játék végére, mint az alacsony Machok. Ez alapvetően annak volt köszönhető, hogy a játék első részében (ahol nem volt büntetés) keveset utaltak át a partnernek, és így több maradt nekik, míg a második felében emelték felajánlásaikat, hogy elkerüljék a büntetést. Eközben erős aktivitásnövekedést mutattak többek között az orbitofrontális kéregben, amely a büntető ingerek kiértékelését, illetve a korábbi válaszok gátlását irányítja.

Hazai $f$ MRI-vizsgálatok ugyancsak arról számoltak be, hogy a machiavellisták specifikus agyi területeket működtetnek döntéseik kialakítása során (BERECZKEI, DEAK, PAPP, Perlaki és OrSI, 2013) Amikor kétszemélyes (Bizalom) játékot játszottak a géppel (amiről úgy tudták, hogy valódi partner), a magas Machszemélyek kevesebbet adtak és kevesebbet is viszonoztak, mint az alacsony Machok. Eközben élénk aktivitás volt megfigyelhető a kétoldali középső frontális tekervényükben, amely közreműködik az ítéletalkotásban és a következtetési folyamatokban, és fontos idegrendszeri komponense a végrehajtó funkcióknak és a mentális rugalmasságnak. Ugyancsak fokozott aktivitást mértek a magas Machpontszámokkal jellemzett személyek jobb oldali talamuszában az alacsony pontszámú játékosokhoz képest. Ismeretes, hogy ez az agyi terület részt vesz - egyebek mellett - a jutalom feldolgozásában és előrejelzésében, fóként bejósolhatatlan feltételek mellett (amilyen egy idegennel folytatott cserekapcsolat). Említsük még meg a magas Mach-személyek cinguláris kérgének aktivitásnövekedését, amely a 
kognitív konfliktusok kezelésének az egyik fő központja. A szerzők értelmezése szerint a machiavellisták erős konfliktust élhetnek át rövid távú érdekeik (az a vágyuk, hogy másokat megrövidítsenek) és hosszú távú érdekeik (az a törekvésük, hogy többet nyerjenek egy stabil, ismétlődő partnerkapcsolatban) között, és ez lehet az oka a szóban forgó agyi terület „tüzelésének”.

\section{MACHIAVELLIÁNUS INTELLIGENCIA}

Az eddig említett pszichológiai kutatásokkal párhuzamosan - de attól lényegében függetlenül - egyes főemlőskutatók is a machiavellista paradigmát kezdték alkalmazni bizonyos viselkedési jelenségek leírására az álltavilágban. Richard BYRNE és Andrew WHITEN skót primatológusok előbb 1988-ban, majd 1997-ben adtak ki egy-egy kötetet Machiavelliánus intelligencia címen. Ebben ők és más szerzők terepmunka-eredményeiket úgy értelmezték, hogy a főemlősök rutinszerűen és szándékosan tévesztik meg fajtársaikat abból a célból, hogy ebből előnyük származzon. Így például galléros páviánoknál figyelték meg, hogy amikor egy fiatal hímet erősebb csoporttársai üldöznek valamilyen okból, az üldözött futás közben hirtelen megáll, két lábra emelkedik, és izgatottan körbefigyel. Ezt általában vészjelzésként használják a ragadozók (elsősorban leopárd) megjelenésekor, de ebben az esetben egyértelműen manipulációs célt szolgált. Nem volt a közelben egyetlen ragadozó sem, a fiatal hím társai megtorpanását arra használta, hogy eltűnjön a bozótban.

Ezeket a terepmunka-eredményeket és magyarázatokat rövidesen egy átfogó evolúciós keretbe emelték. Ehhez érdemes megemlíteni, hogy a csalás evolúciós elemzése már hosszú ideje tanulmányok tárgyát képezte. Richard DAWKins és John KREBS (1978) sokat idézett tanulmányukban elsők között vetették fel, hogy a természetes szelekció bizonyos körülmények között olyan félrevezető jelzések elterjedését részesíti előnyben, amelyek a másik élőlény kihasználására jöttek létre. Ezek lehetnek egyszerủ anatómiai képletek (például a horgászhal csalija), de lehetnek bonyolult „taktikai” megtévesztések (amilyen a föemlősök félrevezető viselkedése). Közös bennük, hogy a jelzést adó élőlény nem a megbízható, kölcsönösen előnyös információ küldésében érdekelt - amilyenek például a dominancia jelzései -, hanem abban, hogy becsapja a vevőt, és ezzel növelje túlélési és szaporodási esélyeit.

A nyolcvanas évektől kezdve kezdték úgy értelmezni, hogy a „machiavelliánus intelligencia” központi szerepet játszott a főemlősök - benne az ember - agyának növekedésében és kognitív képességeinek fejlödésében (BYRNE, 1995; DUNBAR, 1993; WILSON, NEAR és MiLlER, 1996). A folytonosan változó társas környezetben minden olyan viselkedés előnyös volt, amely lehetővé tette a riválisok megtévesztését, különböző koalíciók alakítását a pillanatnyi érdekek szerint és a csalás potenciális áldozatainak a felismerését. Fegyverkezési verseny jött létre: a manipulatív viselkedési technikák tökéletesedése az egyik oldalon bonyolult védekező és elhárító mechanizmusokat hozott létre a másikon, ami még hatékonyabb befolyásolási képességekre szelektált, és így tovább. Ez a folyamat az intelligencia gyors 
növekedéséhez vezetett, ami a mentális képességek hihetetlenül gyors fejlődésében csúcsosodott ki az utolsó kétmillió évben. A főemlősök összehasonlító elemzései valóban megerősítették ezt az elméletet. Kiderült például, hogy a megtévesztő viselkedések aránya szorosan összefügg az agykéreg relatív méretével: a nagyobb agykéreggel rendelkező fajok több manipulatív tevékenységben vesznek részt (BYRNE, 1995).

Sajnos azonban az emberi gondolkodással kapcsolatos kutatások nem siettek alátámasztani a machiavelliánus intelligencia hipotézis elvárásait. Mint láttuk, a relatíve magas Mach-pontokkal rendelkező személyek a legtöbb vizsgálat szerint rosszabb elmeolvasók, mint az alacsony pontszámúak. Hasonlóképpen a legtöbb eddigi vizsgálat úgy találta, hogy a pszichológiateszteken machiavellistaként jellemezhető személy másokhoz képest alacsonyabb szintű érzelmi intelligenciával rendelkezik: rosszabbul fejezi ki az érzelmeit, gyengébb teljesítmény mutat mások érzelmeinek megértésében, és kevésbé képes saját érzelmeinek és érzéseinek az azonosításában és megkülönböztetésében. Ehhez járul még, hogy az általános intelligenciájukat tekintve sem tekinthetők kimagaslóaknak: IQ-értékeik a népesség átlagértékeinek felelnek meg.

Mindezek az eredmények komoly kihívást jelentenek a machiavelliánus intelligencia evolúciós elméletére nézve. Nem jelentenek azonban végzetes és döntő csapást. Amit a kísérleti eredmények tükrében valószínủleg fel kell adni, az az, hogy a machiavellisták fölényt mutatnak a „magasrendű” társas kognitív képességek tekintetében. Magyarul, aligha fogadható el, hogy a természetes szelekció azért hozta létre az elmeolvasás, az érzelmi intelligencia és az empátia kognitív mechanizmusait, mert az összekapcsolódott a manipuláció sikerességével. Ezek valószínűleg más evolúciós-szelekciós folyamatok révén jöttek létre, amelyek ugyancsak a sokrétủ és változékony társas környezet kihívásaihoz való alkalmazkodást szolgálták, de valószínűleg nem a manipuláció területén.

Akkor viszont két, egymáshoz kapcsolódó kérdés merül fel. Egyrészt milyen pszichológiai következményekkel járt a megtévesztés és csalás évmilliókon keresztül folyó gyakorlata, amely a nem-humán főemlősök esetén valószínűleg tényleg hozzájárult az agy evolúciós növekedéséhez. Másrészt az a kérdés vetődik fel, hogy mitől sikeresek a machiavellisták az emberi kapcsolatokban. A két kérdésre azt az egységes választ lehet megfogalmazni, hogy a machiavellista viselkedési stratégiák olyan kognitív képességeire szelektáltak fajunkban, amelyek gyors és hatékony válaszlehetőségeket kínáltak azokban a környezeti szituációkban, ahol sikeres lehetett mások félrevezetése és megrövidítése.

Más szóval, a csalás specifikus kognitív heurisztikákra szelektált. A viselkedési heurisztikák általában véve olyan egyszerű és „takarékos” gyakorlati szabályok, amelyek képesek gyorsan és hatékonyan válaszolni a változó környezet egyedi, gyakran véletlenszerü kihívásaira (TVERSKy és KAHNEMANN, 1983; GigerENZER, 1999). Segítségükkel célszerủ döntéseket tudunk hozni olyan szituációkban is, amikor nincs időnk és lehetőségünk a körülmények mindenoldalú elemzésére. Noha időnként tévedésekhez vezetnek, legtöbbször éppolyan hatékonynak bizonyulnak a mindennapi problémáink megoldásai során, mint az összetett, racionális elemzések. Ennek az az oka, hogy a heurisztikák az ember életének relatíve 
állandó és visszatérő környezeti hatásaira adott válaszként jöttek létre a múltban, ezért az információfeldolgozás hatékony és eredményes mechanizmusait képviselik. Az evolúció során olyan kognitív heurisztikákra szelektálódtunk, amelyek segítségével őseink sikeresen oldották meg alkalmazkodási problémáikat a társas kapcsolatok legkülönbözőbb területein, így például a párválasztás, az anyai gondoskodás vagy a rokonokkal való bánás eseteiben.

Ilyen környezet lehetett az az emberiséggel - sőt a főemlősökkel - egyidős kapcsolatrendszer, amelyben a csoporttagok saját érdekeik érvényesítése miatt manipulálni igyekeztek társaikat. Nem véletlen, hogy számos vizsgálat azt mutatja, hogy az emberek egy része pontosan akkor használja kognitív képességeit mások megtévesztésére, amikor a helyzet lehetővé teszi a sikeres manipulációt. Láttuk korábban, hogy miközben a machiavellisták általában véve gyenge elmeolvasók, nagyon jól értik meg mások cselekvésének mozgató rugóit azokban a szituációkban, ahol az emberek nyilvánvalóan becsapják egymást (SZABÓ és BERECZKEI, 2015). Lehetséges, hogy a machiavellisták egy olyan kognitív heurisztikát alkalmaznak, amely az emberekről alkotott korábbi benyomások alapján dönt a lehetséges viselkedési taktikáról. Ez a heurisztika azt mondja: „Ítéld meg, milyen típusba sorolható az előtted álló ember, és csapd be, ha ez könnyűnek és sikeresnek ígérkezik”. Az sem meglepő, hogy a precíz áldozatkiválasztás fontos eleme a manipulációnak: a machiavellisták akkor vannak elemükben, amikor úgy vélik, hogy a partnerük az együttműködésre és az igazságos elosztásra helyezi a hangsúlyt. Az egyik - korábban ismertetett - vizsgálatból az derült ki, hogy a magas Mach-pontokkal rendelkező személyek másokhoz képest nagyobb figyelmet szentelnek játékostársaik korábbi taktikáinak. Nem annyira saját személyiségvonásaikat követik, inkább a partner megelőző viselkedése alapján kialakított benyomások alapján hozzák meg döntéseiket (CZIBOR és BERECZKEI, 2012).

A machiavellisták másik viselkedési heurisztikája a környezeti hatásokra vonatkozik: „Figyeld meg, melyek azok az ismerős körülmények, amelyek között eredményes lehet a megtévesztés stratégiája”. Általában véve akkor fizetődik ki a csalás, ha alacsony költséggel és nagy haszonnal jár. Egy jelenlegi vizsgálatból az derült ki, hogy a machiavellista személyek egészen másképp viselkednek olyan helyzetben, ahol a társas interakciókat (amelyet egy Közjavak játékban modelleztek) a versengés szabályai szerint kellett lebonyolítani, mint akkor, ha az együttműködés szabályai voltak mérvadók (BERECZKEI és CZIBOR, megjelenés alatt). A versengés körülményei között nem igyekeztek felülmúlni a többieket a nyerészkedésben: hasonló összegeket fizettek be a közösbe, mint az alacsony Mach-pontszámmal rendelkezők. Úgy tủnik, tudatában voltak annak, hogy ahol mindenki versengeni kényszerül a korlátozott jutalomért, ott a manipuláció nem látszik eredményesnek. Mindenki ugyanazt akarja: elnyerni mások pénzét, így viszont a machiavellisták nem jutnak kellő számú balekhoz, és nem tudják kamatoztatni manipulatív taktikáikat. Másként működtek ellenben az együttműködés szituációjában, ahol folyamatosan megrövidítették társaikat, és a végén nagy nyereményre tettek szert. Úgy tűnik, a machiavellisták gyorsan belátták, hogy ott nyílik mód mások kihasználására, ahol az együttműködés normáját követve a többiek sokat adnak a közösbe, és lehet rajtuk élősködni. 
Nyilvánvalóan más heurisztikákra is pozitív szelekció irányulhatott az evolúciós múltban. A kötetben közölt egyik tanulmány azzal a következtetéssel zárul, hogy noha a machiavellistákra általánosságban alacsony érzelmi intelligencia jellemző, egy olyan szituációban, amely a csalásra épít (Svindli kártyajáték), viszonylag jól értelmezik mások érzelmeit, illetve nem-verbális gesztusait, miközben jól leplezik a sajátjaikat (OROSZ és BERECZKEI, 2015). Miközben pedig a machiavellisták átlagos IQ-ja nem különbözik az adott népességre jellemző intelligenciahányadostól, az intelligencia bizonyos komponenseit tekintve átlag fölötti teljesítményt mutatnak. Így például kiváló munkamemóriával rendelkeznek, ami a gyors és rugalmas információfeldolgozással áll kapcsolatban (BERECZKEI és BIRKÁs, 2014). Az ebből fakadó mentális sebesség és komputációs képesség fontos szerepet játszhat a manipulációban egy olyan heurisztika szerint, mint „Hívd elő és játszd végig azokat a lehetőségeket, amelyek hasonló helyzetben korábban is sikerhez vezettek".

\section{ÖSSZEFOGLALÁS}

Mindezek alapján azt mondhatjuk, hogy a „machiavellista intelligencia” olyan információfeldolgozó mechanizmusokat foglal magában, amelyekre hatékony szelekció működhetett a múltban. Noha a machiavellisták másokkal összehasonlítva rosszabb elmeolvasók, alacsonyabb teljesítményt nyújtanak az érzelmi intelligenciában és az IQ-pontszámaik tekintetében sem átlag felettiek, mégis rendelkeznek olyan adottságokkal, amelyek képessé teszik őket a sikeres manipulációra. Gyors és hatékony kognitív heurisztikákat működtetnek a mindennapi problémamegoldás terén, amelyek segítségével képesek reagálni az emberek és a környezeti körülmények jellemző, általános típusaira. Amikor olyan szituációba kerülnek, ahol a megtévesztő stratégia nagyobb haszonnal járhat, mint az együttműködő, „bekapcsolódnak" ezek a heurisztikák. Segítségükkel kiválasztják potenciális áldozataikat, kiértékelik a környezet számukra kedvező vagy kedvezőtlen hatásait, és előhívják a hasonló helyzetre vonatkozó múltbeli tapasztalataikat. Úgy gondoljuk, hogy a machiavellista intelligencia evolúciós feltevése tartható, de nem egészen olyan értelemben, ahogy megalkotói gondolták. A társak szisztematikus és eredményes manipulációja valóban erőteljes szelekciós erő lehetett a múltban, de ez nem az elmeolvasás és intelligencia kidolgozásához vezetett (azt más evolúciós folyamatok végezhették), hanem a környezet specifikus jellemzőinek pontos kiértékeléséhez, a csoporttársak árnyalt kategorizálásához és a rugalmas döntéshozatalhoz. Ezt a feltevést természetesen további vizsgálatokban kell ellenőrizni.

\section{IRODALOM}

Ali, F., Amorim, S., \& Chamorro-Premuzic, T. (2009). Empathy deficits and trait emotional intelligence in psychopathy and Machiavellianism. Personality and Individual Differences, 47, 758-762. 
Ali, F., \& Chamorro-Premuzic, T. (2010). Investigating theory of mind deficits in nonclinical psychopathy. Personality and Individual Differences, 49, 169-174.

Austin, E. J., Farrelly, D., Black, C, \& Moore, H. (2007). Emotional intelligence, Machiavellianism and emotional manipulation: Does EI have a dark side? Personality and Individual Differences, 43, 179-189.

Bereczkei T. (2003). Evolúciós pszichológia. Budapest: Osiris.

BERECZKEI, T., \& BIRKAS, B. (2014). The insightful manipulator: Machiavellians' interpersonal tactics may be linked to their superior information processing skills. International Journal of Psychological Studies, 6(4), 65-70.

BereczkeI, T., \& Czibor, A. (2014). Personality and situational factors differently influence high Mach and low Mach persons' decisions in a social dilemma game. Personality and Individual Differences, 64, 168-173.

BereczKei, T., \& Czibor, A. (megj. előtt). Abusing good intentions: Machiavellians strive for exploiting cooperators. SAGE Open.

Bereczkei, T., Deak, A., Papp, P., Perlaki, G., \& Orsi, G. (2013). Neural correlates of Machiavellian strategies in a social dilemma task. Brain and Cognition, 82, 108-116.

BYrne, R. (1995). Thinking Ape. Evolutionary Origins of Intelligence. Oxford: Oxford University Press.

Byrne, R., \& Whiten, A. (Eds.) (1988). Machiavellian Intelligence. Social Expertise and the Evolution of Intellect in Monkeys, Apes, and Humans. Oxford: Clarendon Press.

Christie, R., \& Geis, F. L. (1970). Studies in machivaellanism. New York: Academic Press.

Czibor, A., \& BereczkeI, T. (2012). Machiavellian people's success results from monitoring their partners. Personality and Individual Differences, 53, 202-206.

DAwkins, R., \& KREBS, J. R. (1978). Animal signals: information or manipulation? In J. R. Krebs, \& N. B. Davies (Eds.), Behavioral Ecology: An Evolutionary Approach (282-309). Oxford: Blackwell Scientific Publication.

DUnBAR, R. I. M. (1993). Coevolution of neocortical size, group size, and language in humans. Behavioral and Brain Sciences, 16, 681-735.

Exlinne, R. V., Thiabaut, J., Hickey, C., \& Gumpart, P. (1970). Visual interaction in relation to Machiavellianism. In R. Christie, \& F. GEIS (Eds.), Studies in Machiavellianism (53-76). New York: Academic Press.

GeIs, F. (1970). The con game. In R. Christie, \& F. GEIS (Eds.), Studies in Machiavellianism (130-160). New York: Academic Press.

Geis, F., \& Levy, M. (1970). The eye of the beholder. In R. Christie, \& F. Geis (Eds.), Studies in Machiavellianism (210-235). New York: Academic Press.

Geis, F., Weinheimer, S., \& Berger, D. (1970). Playing legislature: Cool heads and hot issues. In R. Christie, \& F. GeIS (Eds.), Studies in Machiavellianism (173-189). New York: Academic Press.

Gigerenzer, G. (1999). Ecological Intelligence: An adaptation for frequencies. In D. D. Cummins, \& C. Allen (Eds.), The Evolution of Mind (9-29). Oxford: Oxford University Pess.

Harrell, W. A., \& Hartnagel, T. (1976). The impact of Machiavellianism and the trustfulness of the victim on laboratory theft. Sociometry, 39, 157-165.

Jonason, P. K., \& Webster, G. D. (2012). A protean approach to social influence: Dark Triad personalities and social influence tactics. Personality and Individual Differences, 52, 521-526. 
Jones, D. N., \& Paulhus, D. L. (2009). Machiavellianism. In M. R. Leary, \& R. H. Hoyle (Eds.), Individual Differences in Social Behavior (93-108). New York: Guilford.

Lyons, M., Caldwell, T., \& Schultz, S. (2010). Mind-reading and manipulation - Is Machiavellianism related to theory of mind? Journal of Evolutionary Psychology, 8(3), 261274.

McHoskey, J. W. (1999). Machiavellianism, intrinsic versus extrinsic goals, and social interest: A self-determination theory analysis. Motivation and Emotion, 23, 267-283.

McHoskey, J. W. (2001). Machiavellianism and personality dysfunction. Personality and Individual Differences, 31, 791-798.

McIllwain, D. (2003). Bypassing empathy: A Machiavellian theory of mind and sneaky power. In B. Repacholi, \& V. Slaughter (Eds.), Individual Differences in Theory of Mind (39-66). Hove, E. Sussex: Psychology Press.

Orosz A. és BereczKei T. (2015). A machiavellisták érzelmi intelligenciája társas interakcióban. Magyar Pszichológiai Szemle, 70(1), 23-35.

PAAL, T., \& Bereczkei, T. (2007). Adult theory of mind, cooperation, Machiavellianism: The effect of mindreading on social relations. Personality and Individual Differences, 43, 541-551.

Paulhus, D. L., \& Williams, K. M. (2002). The Dark triad of personality: Narcissism, Machiavellianism, and psychopathy. Journal of Research and Personality, 36, 556-563.

PILch, I. (2008). Machiavellianism, emotional intelligence, and social competence: Are Machiavellians interpersonally skilled? Polish Psychological Bulletin, 39, 158-164.

Spitzer, M., Fischbacher, U., Herrnberger, B., Grön, G., \& Fehr, E. (2007). The neural signature of social norm compliance. Neuron, 56, 185-196.

Sullivan, R. J., \& Allen, J. S. (1999). Social deficits associated with schizophrenia defined in terms of interpersonal Machiavellianism. Acta Psychiatria Scandinavia, 99, 148-154.

SZABÓ E. és BERECZKEI T. (2015). Elmeolvasás és machiavellizmus: a manipuláció szituatív feltérképezése. Magyar Pszichológiai Szemle, 70(1), 37-53.

SzIJJÁRTó L. és BERECZKeI T. (2013). Hidegfejü gondolkodás? Az érzelmi intelligencia és az érzelmi stabilitás szerepe a machiavellista döntéshozatalban. Psychiatria Hungarica, 28, 221-228.

SzIJJARTO, L., \& BereczkeI, T. (2014). The Machiavellians' “cool syndrome”: They experience intensive feelings but have difficulties in expressing their emotions. Current Psychology. A Journal for Diverse Perspectives on Diverse Psychological Issues. DOI: $10.1007 / \mathrm{s} 12144-014-9262-1$.

Tversky, A., \& Kahneman, D. (1983). The framing of decisions and the psychology of choice. Science, 211, 453-458.

VAngelisity, A. L., DAly, J. A., \& Rudnick, J. R. (1991). Making people feel guilty in conversations: Techniques and correlates. Human Communication Research, 18, 3-39.

Wai, M., \& Tiliopulous, N. (2012). The affective and cognitive empathic nature of the dark triad personality. Personality and Individual Differences, 52, 794-799.

Whiten, A., \& Byrne, R. (Eds.) (1997). Machiavellian Intelligence II. Extensions and Evaluations. Cambridge: Cambridge University Press.

Wilson, D. S., Near, D., \& Miller, R. R. (1996). Machiavellianism: A synthesis of the evolutionary and psychological literatures. Psychological Bulletin, 119, 285-299.

ZAJONC, R. B. (1965). Social facilitation. Science, 149, 269-274. 


\title{
THE ART OF MANIPULATION. THE COGNITIVE AND EVOLUTIONARY BASES OF MACHIAVELLIANISM
}

\author{
BERECZKEI, TAMÁS
}

Over the past decade, unexpected findings have been uncovered in the research of Machiavellianism. Whereas a lot of results of the former social psychological studies were confirmed, several assumptions must have been reconsidered. Machiavellian people, in fact, are "cold-minded" people but they also appear to experience intensive emotions in their social relationships. At the same time they are skilled at concealing these emotions that may promote the successful deception. In spite of the former theoretical expectations, Machiavellians poorly perform mindreading tests, but they can make relatively accurate judgments about their potential victims' typical personality character. They wish immediate reward but they are able to adjust their decisions to the actual demands of the social situation, on long run. All of these characteristics may coincide with the Machiavellian intelligence hypothesis stating that manipulation played a crucial role in the evolution of primate cognitive abilities. The exploitation of the group members might be a strong selectionary force during human evolution that led to the development of flexible decision making, to the permanent monitoring of others, and to the precise evaluation of the particular features of the social environment.

Key words: emotional intelligence, mindreading, cognitive heuristics, social intelligence 